Reprod. Nutr. Dévelop., 1988, 28 (2 B), 473-486.

\title{
Melatonin patterns in ewes maintained under skeleton or resonance photoperiodic regimens
}

\author{
J. P. RAVAULT, J. THIMONIER
}

with the technical assistance of Agnès DAVEAU, D. CHESNEAU and Françoise MAURICE

Station de Physiologie de la Reproduction, I.N.R.A., Nouzilly, 37380 Monnaie, France.

\begin{abstract}
Summary. Two experiments were designed to study the mechanism for measurement of daylength by ewes.

$\left.1^{\circ}\right)$ Two groups of 8 adult ewes were exposed for more than one year to either 16L : 8D (long days) or 7L : 9D : 1L : 7D alternated every 3 months with $8 \mathrm{~L}: 16 \mathrm{D}$ (short days). Ovulatory activity was followed during the total duration of the experiment and compared to that of a third group of 8 females under simulated natural conditions of lighting. Plasma prolactin and melatonin were measured in blood samples collected hourly over a 24-h period, more than 1.5 months after a light shift.

Ovulatory activity and patterns of prolactin showed that one hour of light given 16 to 17 hours after the onset of the main light phase led to the measurement of a long day by the animals. Plasma melatonin was high during darkness in ewes under 8L : 16D or $16 \mathrm{~L}: 8 \mathrm{D}$. So, the duration of melatonin secretion was about twice as long in short days (8L : $16 \mathrm{D})$ as in long days $(16 \mathrm{~L}: 8 \mathrm{D})$. Interruption of the dark phase by the light pulse induced a dramatic decrease in the melatonin levels which increased again in only 6 of the 8 ewes studied.
\end{abstract}

$\left.2^{\circ}\right)$ Four groups of 7-8 ewes were subjected for at least 6 months to one of the following treatments: $4 \mathrm{~L}: 8 \mathrm{D}, 4 \mathrm{~L}: 20 \mathrm{D}, 4 \mathrm{~L}: 32 \mathrm{D}$ or $4 \mathrm{~L}: 44 \mathrm{D}$. Blood samples were collected twice each week in order to monitor the ovulatory activity and plasma prolactin levels. In addition, to follow the plasma prolactin and melatonin patterns, blood samples were collected hourly over a 48-h period, 4 months after the onset of the experiment.

The ovulatory activity was not indicative of the daylength measured by the animals. However, plasma prolactin levels suggested that $4 \mathrm{~L}: 8 \mathrm{D}$ and $4 \mathrm{~L}: 32 \mathrm{D}$ were considered as long days and $4 \mathrm{~L}: 20 \mathrm{D}$ as short days. Four months after the onset of the experiment, a 24-h rhythm of melatonin secretion was found regardless of the photoperiodic treatment : in all groups, low melatonin levels were coincident in time once every $24 \mathrm{~h}$, and high melatonin levels displayed similar coincidence. Low levels of melatonin were observed during each period of light. Melatonin secretion was interrupted by light in groups $4 \mathrm{~L}: 8 \mathrm{D}$ and $4 \mathrm{~L}: 32 \mathrm{D}$, both treatments to which the ewes responded as long days.

Results of both experiments are compatible with the hypothesis that periods of melatonin secretion throughout the day are more important than the duration of secretion itself.

\section{Introduction.}

Melatonin is undoubtedly involved in the mechanism of action of light on gonadotrophic function. According to Goldman and Darrow (1983) and Carter 
and Goldman (1983), duration of melatonin secretion is the most important factor involved in the measurement of daylength by the Djungarian hamster. In the ewe, melatonin secretion occurs proportionaly to the length of the night (Rollag et al., 1978), and in pinealectomized animals circulating levels of $\mathrm{LH}$ adjust to the duration of melatonin infusion and not to the actual length of the night (Bittmann and Karsch, 1984).

While these findings strongly support the importance of the duration of melatonin secretion, other results must be considered. Skeleton photoperiod experiments indicate that light pulses as short as one second, given at specific times after dawn, evoke the responses corresponding to long days in the golden hamster (Ellis and Follett, 1983). Similarly, in the ram and the ewe, one hour of light given 16-17 $\mathrm{h}$ after dawn induces physiological responses characteristic of long days (Pelletier et al., 1981 ; Thimonier, 1981). Moreover, a dynamic light pulse in which the delay to dawn increases from 8 to $16 \mathrm{~h}$ and then decreases to $8 \mathrm{~h}$ over a six month period, entrains gonadotrophic activity and testicular size of rams in a manner similar to that of controls receiving light in only one block (Pelletier and Thimonier, 1987). These different results suggest that animals measure daylength between two limits regardless of whether the interval is fully illuminated or not. However, in terms of mechanism of light action, these different studies lack plasma melatonin measurements. This prompted us to examine the correspondence between daylength measurement and melatonin secretion in ewes subjected to either skeleton or resonance experiments.

\section{Night interruption experiment}

\section{Material and methods.}

Three groups of 8 adult lle-de-France ewes were involved in this experiment (Fig. 1). The first group (A) was maintained under simulated normal variations of daylength at the latitude of $47^{\circ} \mathrm{N}$. The ewes of the second group (B) were exposed to alternating 3 month periods of constant long (16L : 8D) and constant short (8L : 16D) days. The females of the third group (C) were subjected to the alternation every 3 months of two schedules of $\mathbf{8 h}$ of light. In one of these, the light was presented during 2 periods (7L : 9D : 1L : 7D), while in the other it was presented in a single, continuous period (8L : 16D).

The females of a given group were penned in a $10 \mathrm{~m}^{2}$ light-proof room. The light intensity was approximately $350 \mathrm{~lx}$ at the eye level of a standing ewe at the center of the room. Temperature inside the rooms varied from a minimum of $0{ }^{\circ} \mathrm{C}$ in winter up to a maximum of $30^{\circ} \mathrm{C}$ in summer. Ewes were fed daily between 8 and $9 \mathrm{a} . \mathrm{m}$. with $300 \mathrm{~g}$ dehydrated lucerne, $500 \mathrm{~g}$ wheat, and $800 \mathrm{~g}$ straw per head plus minerals and vitamins. Water was available ad libitum.

Blood samples of the ewes in all groups were collected twice a week on Tuesdays and Fridays between 9 and 10 a.m. Plasma samples were assayed for progesterone according to the method described by Terqui and Thimonier (1974) in order to monitor ovulatory activity (Thimonier, 1978). Hourly blood samples 

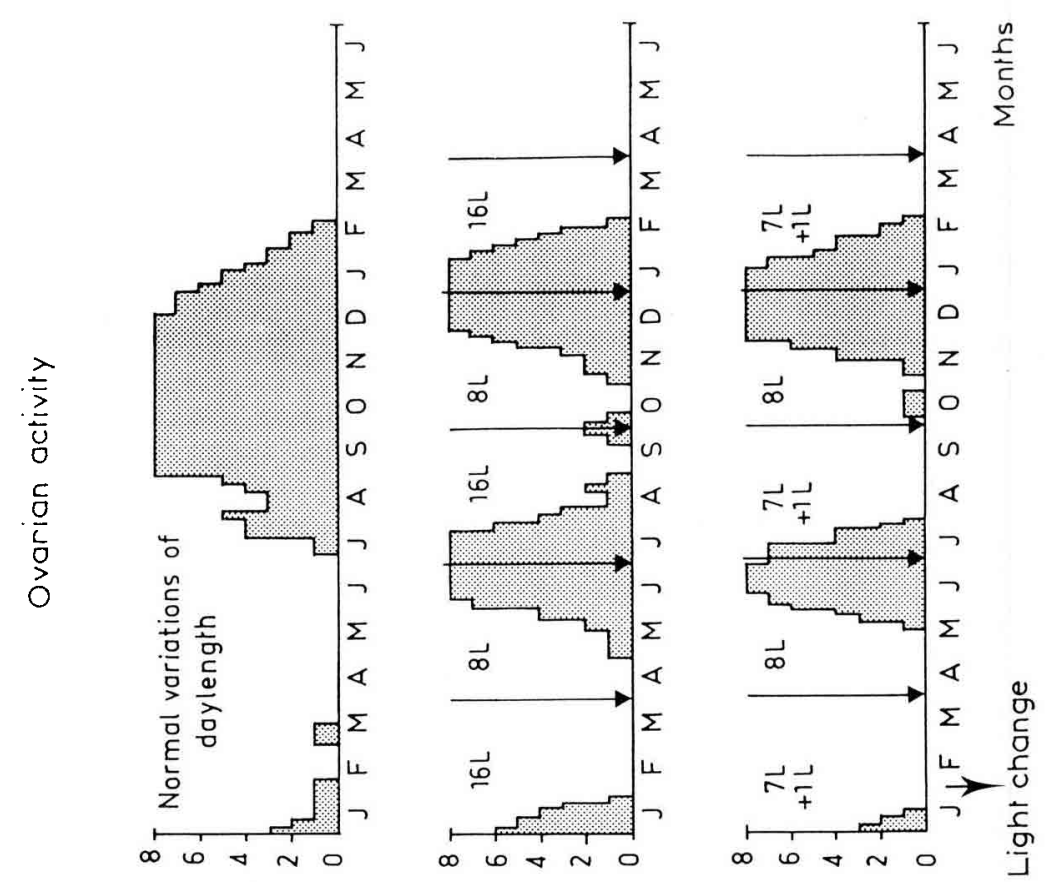

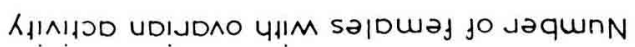

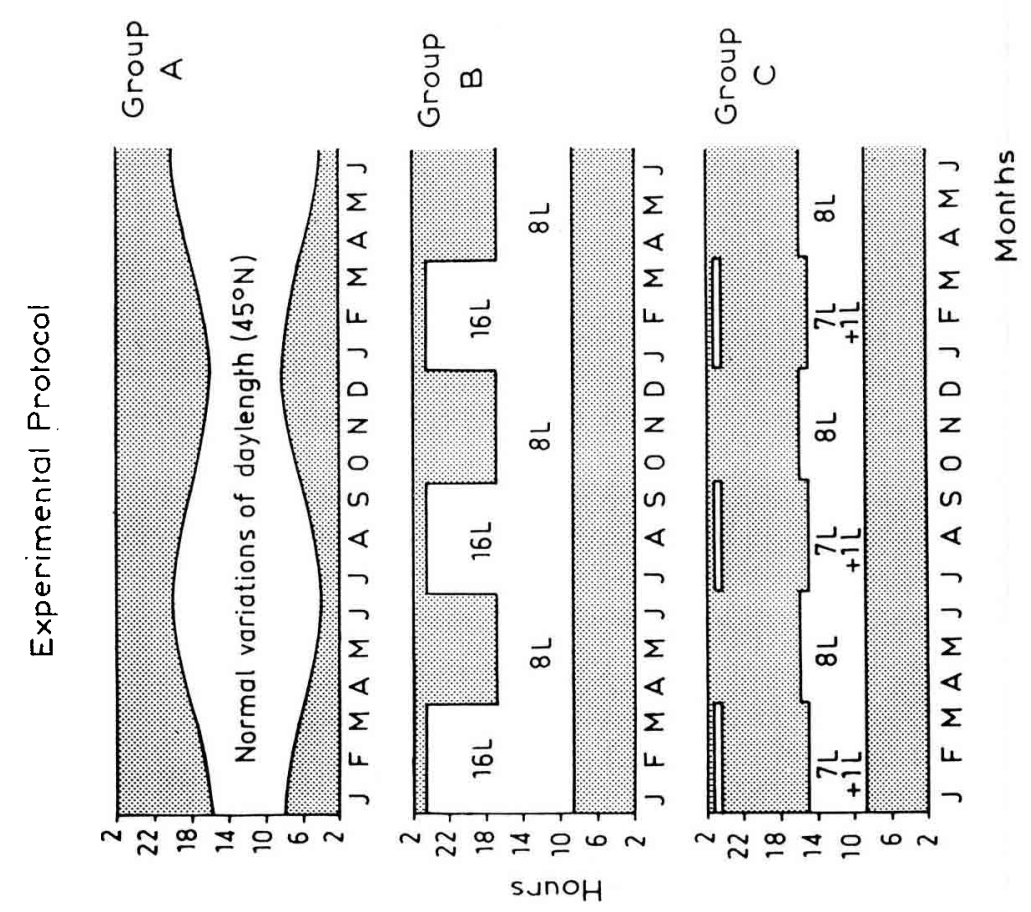

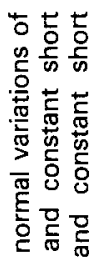

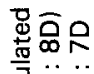

है흘.

ष뭉요

드.

눈

贾船

若苍势

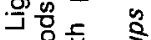

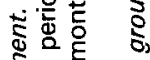

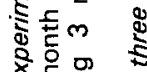

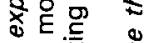
కm产

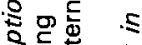
농 芯造 S... को

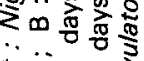

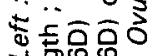
홑으‥

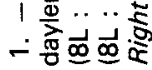
문 
over a period of 24 hours and within 15 min before and after a light change were taken on 2 occasions in groups $B$ and $C$ :

- 64 days after a change from $8 \mathrm{~L}: 16 \mathrm{D}$ to either $16 \mathrm{~L}: 8 \mathrm{D}$ (group $\mathrm{B}$ ) or 7L : 9D : $1 \mathrm{~L}: 7 \mathrm{D}$ (group C).

- 40 days after a change from $16 \mathrm{~L}: 8 \mathrm{D}$ (group $\mathrm{B}$ ) or $7 \mathrm{~L}: 9 \mathrm{D}: 1 \mathrm{~L}: 7 \mathrm{D}$ (group $\mathrm{C}$ )

to $8 \mathrm{~L}: 16 \mathrm{D}$. In this case blood samples from only 4 ewes per group were collected.

During the dark phases, blood samples were taken using a dim red light.

The hourly plasma samples were assayed for prolactin according to the method described by Kann (1971) and for melatonin according to the method adapted from Fraser et al. (1983).

\section{Results.}

$\left.1^{\circ}\right)$ Twenty four hour melatonin patterns.

a) Mean melatonin patterns in groups $B$ and $C$.

- Mean melatonin levels were low when the light was on and elevated when the light was off for ewes exposed to long (16L : 8D) (Fig. 2A) or short (8L : 16D) days. Forty days after the light changes, the patterns of melatonin were identical for ewes under $8 \mathrm{~L}: 16 \mathrm{D}$ regardless of their previous light treatment (16L : 8D or 7L : 9D : 1L : 7D). Thus the duration of the period of high levels of melatonin was approximately twice as long for ewes under $8 \mathrm{~L}: 16 \mathrm{D}$ as for those under $16 \mathrm{~L}: 8 \mathrm{D}$.

- For females under the $7 \mathrm{~L}: 9 \mathrm{D}: 1 \mathrm{~L}: 7 \mathrm{D}$ condition, the mean melatonin levels were low during the 2 periods of light ( $7 \mathrm{~L}$ and $1 \mathrm{~L})$, whereas during the 2 periods of darkness (9D and 7D) they were high (Fig. 2B). Consequently, the mean duration of the total periods of high levels of melatonin was similar to that observed in ewes maintained under long days (16L : 8D) (Fig. 2A).

- In all the groups, within 15 min after light-dark and dark-light shifts, there were obvious increases and decreases of the mean melatonin levels, respectively.

\section{b) Individual melatonin patterns.}

In all ewes, plasma melatonin patterns were high during darkness (group B under $16 \mathrm{~L}: 8 \mathrm{D}$ ) or during the first block of $9 \mathrm{~h}$ of darkness (group C) despite some variations between samples in individuals. By contrast, the individual patterns of melatonin during the second block of darkness following the 1 hour pulse (group C) differed markedly:

-2 of the 8 ewes had no further increase in melatonin levels, which were then similar to those observed during the main period of light (Fig. 2C) ;

-6 ewes had an increase in the melatonin levels; in two of them, the levels were elevated and sustained during the entire period of darkness (Fig. 2D). 


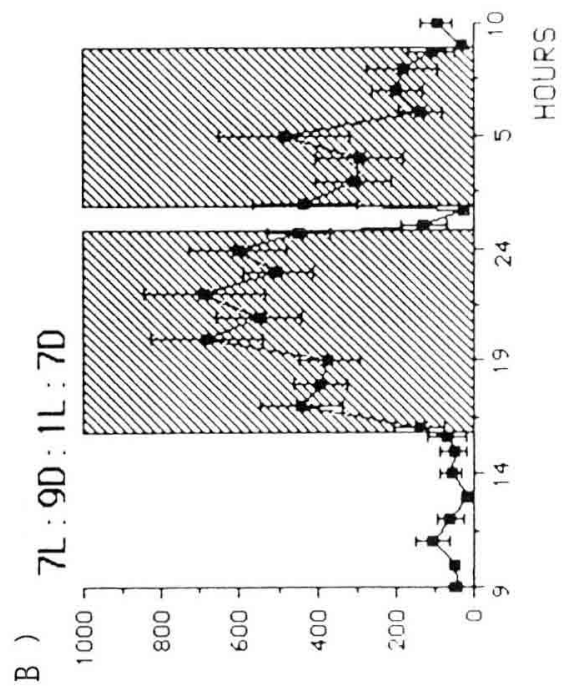

( TW/ 9d) NINOLY7JW

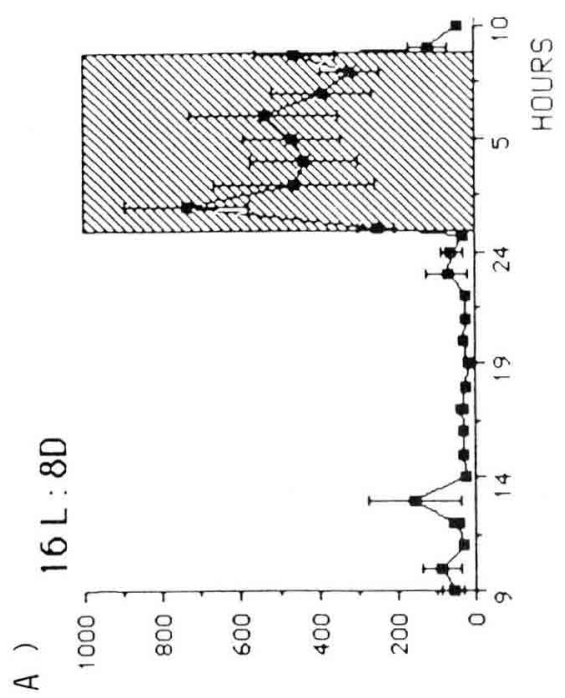

( $7 W / 9 d)$ NINOL $\forall 7 \exists W$

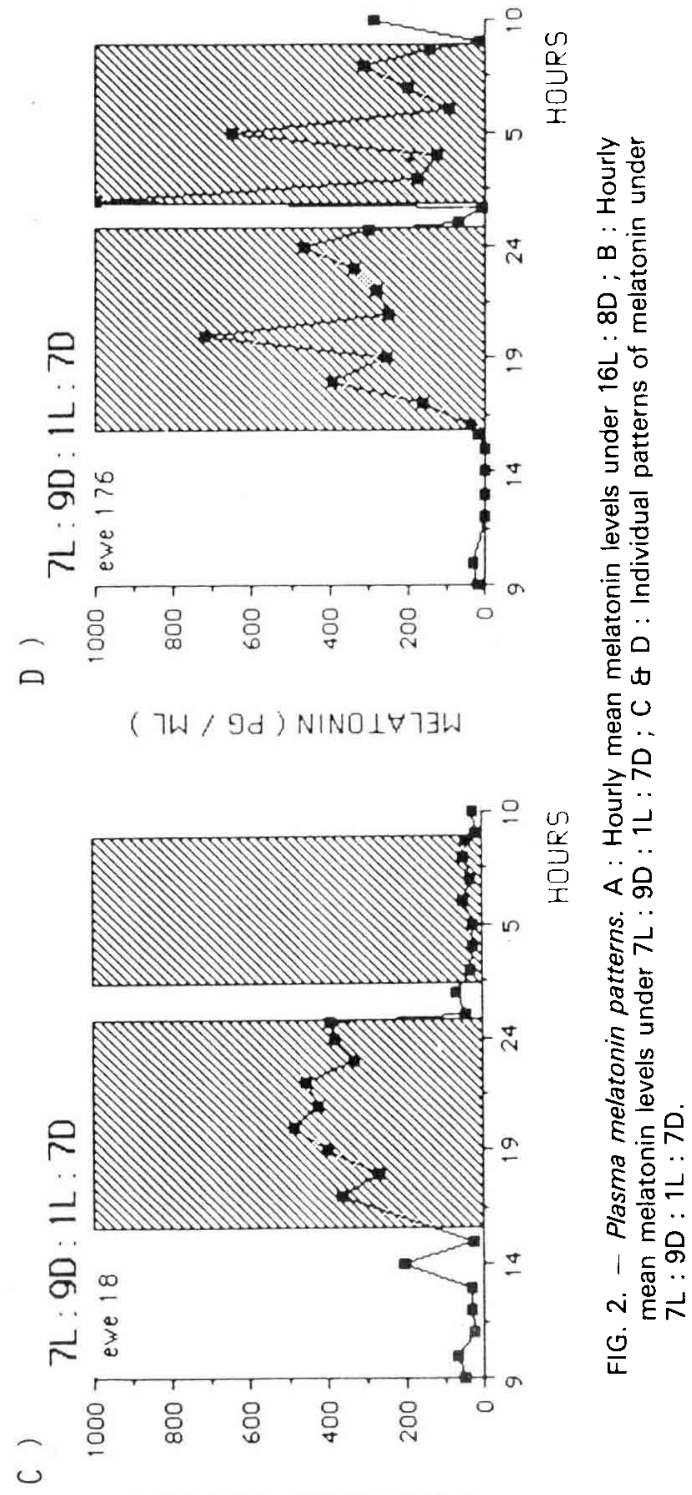

( $7 w / 9 d$ ) NINOL $\forall 73 W$ 


\section{$\left.2^{\circ}\right)$ Twenty four hour prolactin patterns.}

The mean $24-\mathrm{h}$ prolactin levels were significantly lower $(52 \pm 4 \mathrm{ng} / \mathrm{ml})$ in ewes maintained under short days than in ewes under either long days $(16 \mathrm{~L}: 8 \mathrm{D} ; 333 \pm 13 \mathrm{ng} / \mathrm{ml})$ or the skeleton photoperiod $(7 \mathrm{~L}: 9 \mathrm{D}: 1 \mathrm{~L}: 7 \mathrm{D}$; $393 \pm 13 \mathrm{ng} / \mathrm{ml})$.

The individual patterns between ewes within groups and, particularly, in ewes under the skeleton photoperiod were very similar, regardless of whether or not the ewes had high melatonin levels during the second period of darkness (7D). The ranges of mean 24-h prolactin levels were 67-88, 265-398 and $328-484 \mathrm{ng} / \mathrm{ml}$ in ewes under $8 \mathrm{~L}: 16 \mathrm{D}, 16 \mathrm{~L}: 8 \mathrm{D}$ and $7 \mathrm{~L}: 9 \mathrm{D}: 1 \mathrm{~L}: 7 \mathrm{D}$, respectively. A sharp significant increase occurred just after onset of the dark period in ewes under $16 \mathrm{~L}: 8 \mathrm{D}$, and the mean level during the period of darkness for the females of this group was significantly higher than during the period of light. In contrast, there were no clear 24-h prolactin patterns in ewes under short days or the skeleton photoperiod although the mean levels of prolactin were slightly lower during the light pulse.

\section{$\left.3^{\circ}\right)$ Ovulatory activity.}

Each shift from $16 \mathrm{~L}: 8 \mathrm{D}$ or $7 \mathrm{~L}: 9 \mathrm{D}: 1 \mathrm{~L}: 7 \mathrm{D}$ to $8 \mathrm{~L}: 16 \mathrm{D}$ induced a period of ovulatory activity after approximately 50 days (Fig. 1). Each change from 8L : 16D to either $16 \mathrm{~L}: 8 \mathrm{D}$ or $7 \mathrm{~L}: 9 \mathrm{D}: 1 \mathrm{~L}: 7 \mathrm{D}$ resulted in ovarian inactivity within about 35 days. Females of groups $B$ and $C$ experienced 2 periods of ovulatory activity while the controls (group A) had only one.

\section{Discussion.}

Alternating 3 month periods of constant long (16L:8D) and constant short days (8L : 16D) induced in the lle-de-France ewe a pattern of ovulatory activity and inactivity similar to that observed in the Suffolk ewe (Karsch et al., 1984). The patterns of ovulatory activity also indicated that $1 \mathrm{~h}$ of light given 16 to $17 \mathrm{~h}$ after the onset of a main light phase of $7 \mathrm{~h}$ has the same effect as a long day $(16 \mathrm{~L}: 8 \mathrm{D})$. Such a result was already suggested in a previous experiment (Thimonier, 1981): the onset of ovarian activity occurred earlier when ewes which had been primed with $1 \mathrm{~h}$ of light 16 to $17 \mathrm{~h}$ after a main light phase of $7 \mathrm{~h}$ were subjected to $8 \mathrm{~h}$ of light than when they were maintained under the priming treatment.

Such a skeleton photoperiod has also proven to be physiologically equivalent for growth : lambs under 7L : 9D : 1L : 7D have similar food intake and efficiency and similar growth as lambs under long days (Schanbacher and Crouse, 1981).

It thus appears that the periods of lighting during the nycthemeral rhythm are more important than the total duration of lighting. This has also been 
demonstrated in the ram under dynamic light conditions, that is, when the position of the light pulse relative to the onset of the main light phase changed daily (Pelletier and Thimonier, 1987). Finally, this concept was also supported with prolactin secretion: high prolactin levels in sheep under the skeleton photoperiod indicated that a light pulse given 16 to $17 \mathrm{~h}$ after dawn is equivalent to a long day (present data ; Ravault and Ortavant, 1977 ; Thimonier et al., 1978 ; Schanbacher and Crouse, 1981).

When rams are subjected to night-interruption experiments, melatonin levels decrease during the light pulse (Lincoln et al., 1985). This decrease has been related in sheep to a decrease in $\mathrm{N}$-acetyl transferase activity during the light pulse (Namboodiri et al., 1985). In the hamster, melatonin secretion is sensitive to a light pulse as short as 5 s (Reiter et al., 1986). In the goat, a 2-h light pulse in the middle of the dark phase caused only a transitory suppression of melatonin levels, but the consequences of such a light schedule on the reproductive activity are unknown (Maeda et al., 1984). Given later in the night, 10 to $11 \mathrm{~h}$ after the onset of darkness, a 1-h light pulse induced a longer suppression of melatonin secretion (Brinklow et al., 1984 ; Earl et al., 1985). It is therefore hypothesized that the light pulse induced a phase advance in the morning decline of $\mathrm{N}$-acetyl transferase activity (IIInevora and Vanecek, 1982a,b). It then acted as a dawn signal and the physiological response corresponded to a long day.

In the present experiment, such an hypothesis can be applied to only 2 of the 8 females of the $7 \mathrm{~L}: 9 \mathrm{D}: 1 \mathrm{~L}: 7 \mathrm{D}$ group. For the other ewes a second block of melatonin secretion occurred after the light pulse. So, in some ewes (Fig. 2D), the total duration of secretion during a day was comparable to that of ewes under a short day, whereas ovarian activity and prolactin levels indicated that all of them had measured a long day.

It seems that for the majority of ewes the mere absence of melatonin secretion during the light pulse was sufficient to code for a long day. It is also possible that the melatonin decline acted as a switch for the timing. The second block of melatonin secreted after the pulse appears unimportant as previously observed by Goldman (1983) in the hamster. Consequently, daylength measurement by animals is not really linked to the actual total duration of melatonin secretion per day.

\section{Resonance experiment}

\section{Material and methods.}

Four groups of 7 or 8 adult lle-de-France ewes were exposed to the following light treatments beginning on January $15: 4 \mathrm{~L}: 8 \mathrm{D}$ (group $\mathrm{A}$ ), 4L : 20D (group B), 4L : 32D (group C), 4L: 44D (group D) (Fig. 3). Previously they were subjected to normal variations of daylength at the latitude of $47^{\circ} \mathrm{N}$. The general management and conditions of the females were similar to those of the first experiment. Ewes were fed daily between 8 and 9 a.m., in the dark if necessary.

Blood samples were collected twice each week on Tuesdays and Fridays between 9 and 10 a.m., regardless of whethar the light was on or off. When the 

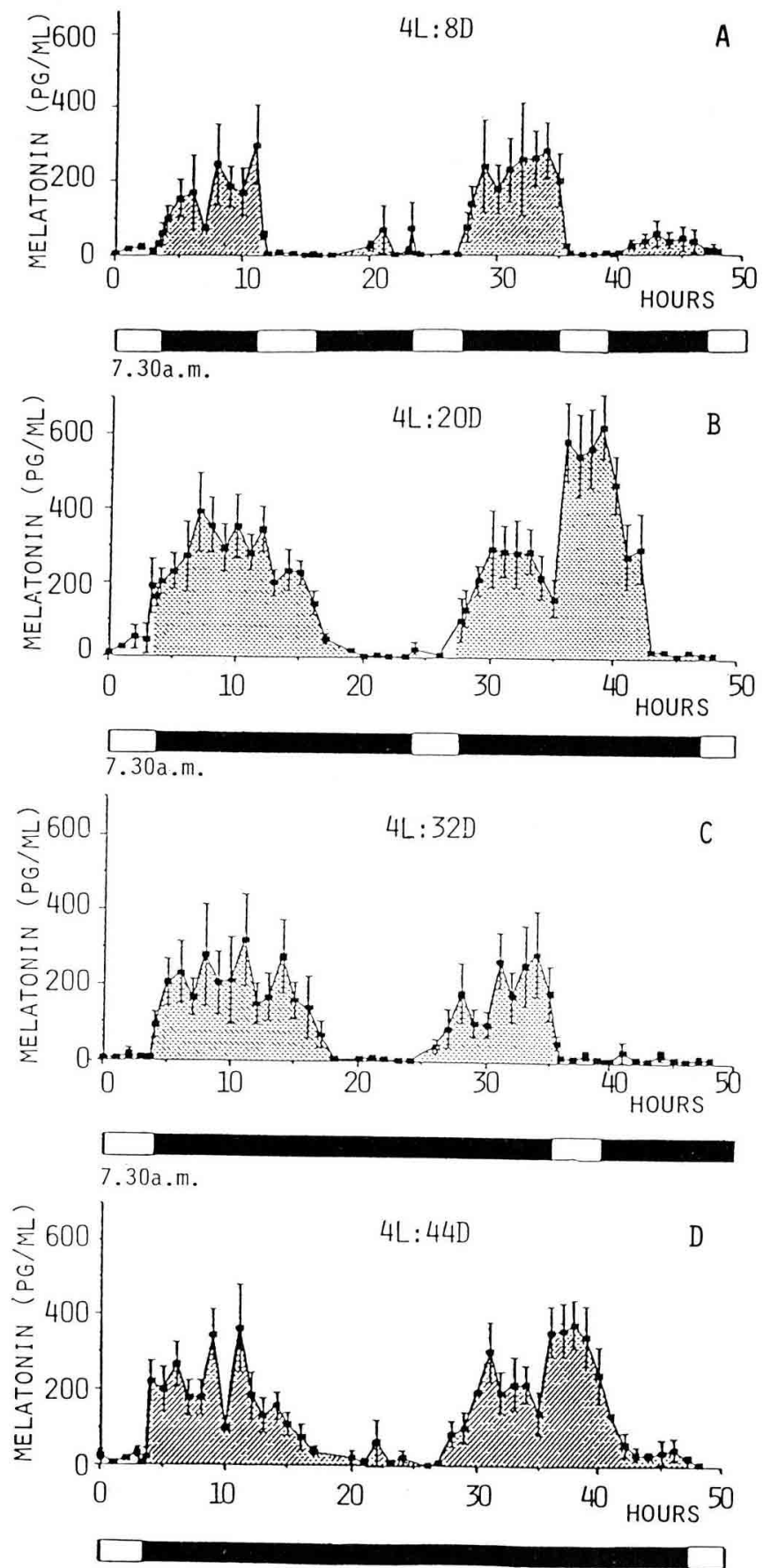

7.30a.m.

FIG. 3. - Resonance experiment. Light treatments and hourly mean melatonin levels under : A : 4L: $8 \mathrm{D} ; \mathrm{B}: 4 \mathrm{~L}: 20 \mathrm{D} ; \mathrm{C}: 4 \mathrm{~L}: 32 \mathrm{D} ; \mathrm{D}: 4 \mathrm{~L}: 44 \mathrm{D}$

Periods of darkness are indicated by the horizontal black bar. 
light was off a dim red light was used to facilitate blood collection. Four months after the beginning of the light treatments, hourly blood samples were taken for $48 \mathrm{~h}$ and within $15 \mathrm{~min}$ before and after a light change. Twice a week, plasma samples were assayed for progesterone according to the method described by Terqui and Thimonier (1974) in order to determine the periods of ovulatory activity (Thimonier, 1978) and assayed for prolactin according to Kann (1971). Hourly blood samples were also assayed for prolactin and melatonin (method adapted from Fraser et al., 1983).

\section{Results.}

\section{0) Melatonin patterns.}

The cosinor analysis demonstrated a 24-h rhythm in the patterns of the melatonin levels of all the ewes of the 4 groups. Basically, only one main block of melatonin secretion was observed per $24 \mathrm{~h}$ in each group despite periods of darkness greater than $24 \mathrm{~h}$ in groups C and D (Fig. 3). Indeed, high levels of melatonin were never sustained for more than $16 \mathrm{~h}$. In only one ewe of group $A$ were high melatonin levels present at each of the four periods of darkness. Consequently, females of groups $B$ and $D$ had high melatonin levels corresponding with one of two periods of light of group $A$ and females of group $C$ with only one of the four observed periods.

Increases of melatonin levels were observed following darkness onset at 11 : 30 a.m. in groups $A$ to $D$ the first day of blood collection or during darkness at approximately $11: 30$ a.m. the second day in groups $C$ and D. However, a light offset at $11: 30 \mathrm{p}$. m. was generally not followed by an increase in melatonin secretion in groups $A$ and $C$ : four of 15 ewes only, including that in group $A$ mentioned above, had occasional high melatonin values $(>70 \mathrm{pg} / \mathrm{ml})$.

Light onset occurring when melatonin levels were high, always induced a drop in these levels, which remained consistently low during the entire light period. In addition, low levels of melatonin occurred at the same time in each group for 5-6 $\mathrm{h}$ within the period 2-8 a.m., regardless of whether the lights were on or off.

\section{$2^{\circ}$ ) Prolactin patterns.}

At the onset of the experiment in January, the mean prolactin levels were low in the four groups (overall mean : $80 \pm 37 \mathrm{ng} / \mathrm{ml}$ ). In the second month, groups $A$ and $C$ were characterized by a large increase in prolactin levels, which remained high from February to the end of April. In contrast, prolactin levels increased progressively in the $B$ and $D$ groups. Because the mean plasma values in all groups did not vary significantly from February to April, the values were pooled and mean prolactin levels for this period were found to be $238 \pm 23$, $92 \pm 14,257 \pm 25$ and $194 \pm 27 \mathrm{ng} / \mathrm{ml}$ for groups $\mathrm{A}, \mathrm{B}, \mathrm{C}$ and $\mathrm{D}$, respectively. 
During the 48-h periods of blood collection in early May, the prolactin levels did not show a circadian pattern in any group. The mean prolactin levels were $327 \pm 15,160 \pm 10,260 \pm 14$ and $241 \pm 15 \mathrm{ng} / \mathrm{ml}$ in groups $A, B, C$ and $D$, respectively. The prolactin levels during light periods were similarly $364 \pm 43$, $124 \pm 23,328 \pm 43$ and $255 \pm 30 \mathrm{ng} / \mathrm{ml}$ in these groups.

In all these cases prolactin levels in group $B$ were significantly lower $(P<0.01)$ than in any of the other groups.

\section{$\left.3^{\circ}\right)$ Ovulatory activity.}

In all groups, some females showed ovulatory activity by January 15 , the beginning of the experiment. They were all anovulatory by the end of March. Erratic ovulatory cycles were observed in 1 or 2 females of each group in April or May. The median dates for the first regular ovulatory cycles were similar for ewes under 4L : 8D, 4L : 32D and 4L: 44D and were, respectively, 25 June, 2 July and 12 June. In each of these three groups, however, 1 or 2 ewes were either still anovulatory by the end of the period of observation or demonstrated erratic ovulatory cycles. By the end of August, 5 of the 8 ewes under 4L:20D had experienced at least one ovulatory cycle but their cycles were still irregular.

\section{Discussion.}

From the patterns of ovulatory activity, it is not possible to determine the measurement of daylength by the different groups of females, although group $B$ females (4L: 20D) had a larger delay in the resumption of ovulatory activity than females of Groups A, C and D. This suggests that the $4 \mathrm{~L}: 20 \mathrm{D}$ regimen coded for a short day.

Under constant daylight regimens, regardless of duration, onset and offset of the oestrous or ovulatory activity can occur (Ducker et al., 1973; Thimonier et al., 1978). In the present experiment, priming light treatments (long or short days) would have helped to demonstrate differences in the measurement of daylength by the different groups.

Prolactin levels in sheep are closely related to daylength and provide a good indicator of the daylength measurement by animals. Under normal photoperiodic variations, the lowest levels are observed during short days and the highest during long days (Ravault, 1976 ; Thimonier et al., 1978). Under artificial conditions, prolactin levels are also low during short days and high during long days (Lincoln et al., 1982 ; D'Occhio et al., 1984 ; Poulton and Robinson, 1987), and there is good evidence that prolactin secretion depends on the photoperiodic drive (Pelletier, 1973). At the onset of the experiment, prolactin levels were low as a result of natural short days. The large increase observed in the second month of the experiment, in groups $A$ and $C$ indicates that the two corresponding treatments, $4 \mathrm{~L}: 8 \mathrm{D}$ and $4 \mathrm{~L}: 32 \mathrm{D}$, were perceived as long days. The lower prolactin levels in females of group $B$ are indicative of the measurement of a short 
day. Nevertheless, in the four groups, although the ewes were under constant light regimens, an increase in the mean prolactin levels was observed. Such a variation under constant light treatments has already been observed (Thimonier et al., 1978) indicating that other environmental factors or a circannual endogenous rhythm may drive prolactin secretion.

Undoubtedly, the mean $48 \mathrm{~h}$ prolactin levels observed in group B 4 months after the onset of the experiment are typical of a short day, whereas in groups $A$ and $C$ they are representative of a long day. Mean $48 \mathrm{~h}$ levels in group $D$ are intermediate and make the measurement of daylength in this group of females questionable.

Regarding melatonin secretion, the most striking phenomenon is the maintenance of a 24-h rhythm 4 months after the onset of the experiment. The synchronization between all animals is evident at the times of low levels of melatonin, which were observed every $24 \mathrm{~h}$, regardless of the presence of light. Such a synchronization may be a result of the light treatments themselves. The rhythm and the synchronization may have also been artificially maintained by collection of blood samples of ewes at the same times twice each week, or by a regular 24-h feeding schedule. Periods of high melatonin secretion were nearly twice as long in groups $B(4 \mathrm{~L}: 20 \mathrm{D})$ and $D(4 \mathrm{~L}: 44 \mathrm{D})$ as in group $A(4 \mathrm{~L}: 8 \mathrm{D})$. In group $C(4 \mathrm{~L}: 32 \mathrm{D})$, the first block of high melatonin levels had a duration similar to that found in group $B$ or $D$ and the second one was comparable to that shown in group $A$.

The melatonin secretion is dependent upon two phenomena :

- its own nervous and/or neuroendocrine regulation as can be seen in groups $B$ and $D$, in which, even during darkness, the duration of melatonin secretion is limited to approximately 16 hours, a finding previously observed by Almeida and Lincoln (1982) ;

- a light-induced decrease observed on each occasion, in contrast to the results of Almeida and Lincoln (1982).

Although light onset stops melatonin secretion, light offset does not always provide the "melatonin on " signal as shown in groups $A$ and $C$.

In different species of mammals involved in resonance experiments (hamster : Elliott et al., 1972 ; vole : Grocock and Clarke, 1974 ; ram : Almeida and Lincoln, 1982 ; mink : Boissin-Agasse et al., 1986), light recurring every 12 or $36 \mathrm{~h}$ is perceived by the animals as long days, while that recurring every 24 or $48 \mathrm{~h}$ is measured as short days. Basically, our present data agree with these various results.

\section{Conclusion.}

1) The first skeleton experiment indicates that long day measurement by ewes was independent of the presence or absence of the second block of melatonin secretion following the light pulse. If these melatonin patterns are repeated day after day in the same individuals, a long day is measured with a total melatonin secretion of variable duration up to 16 hours per day. It appears that 
only the first block of melatonin secretion before the light pulse was utilized for daylength measurement. Consequently, the measurement of daylength was not related to the total duration of melatonin secretion per day.

2) The previous conclusion, which does not agree with the duration hypothesis for the measurement of daylength, opens the field to other hypotheses related to the timing of the melatonin secretion, including its absence at period(s) of the circadian cycle. Both the night-interruption and resonance experiments are compatible with the idea that sheep, like other photoperiodic species, measure daylength between two limits, with continuous lighting between these two limits being unnecessary. This view is consistent with the existence of a photosensitive phase for prolactin and gonadotrophins in rams (Ortavant, 1977 ; Ravault et al., 1981 ; Pelletier et al., 1981). It also agrees with a more general system of daylength measurement specified by various models of coincidence arising from the Bunning hypothesis.

Colloquium on "Neuroendocrine mechanisms and light control of reproduction in domestic mammals " I.N.R.A., Nouzilly, 17-18 September 1987.

Résumé. Effet du fractionnement et de la périodicité de la phase claire sur la sécrétion de la mélatonine chez la brebis.

Deux expériences ont été réalisées pour préciser les mécanismes de la lecture de la durée du jour chez la brebis.

$\left.1^{\circ}\right)$ Deux groupes de brebis adultes ont été soumis pendant plus d'un an à l'alternance tous les 3 mois de régimes lumineux soit $16 \mathrm{~L}: 8 \mathrm{D}$ (jours longs) soit $7 \mathrm{~L}: 9 \mathrm{D}: 1 \mathrm{~L}: 7 \mathrm{D}$ avec un régime $8 \mathrm{~L}: 16 \mathrm{D}$ (jours courts). L'activité ovulatoire a été suivie pendant toute la durée de l'expérience. La prolactine et la mélatonine plasmatiques ont été mesurées dans des échantillons sanguins collectés chaque heure pendant $24 \mathrm{~h}$ plus de 1,5 mois après un changement de régime photopériodique.

L'évolution de l'activité ovulatoire et les niveaux de prolactine indiquent qu'une heure de lumière donnée 16-17 heures après le début de la phase claire principale est lue par les brebis comme un jour long. La mélatonine est élevée pendant la phase obscure chez les brebis aussi bien lorsqu'elles sont en $8 \mathrm{~L}: 16 \mathrm{D}$ qu'en 16L : 8D. La durée de sécrétion est donc presque 2 fois plus longue en jour court $(8 \mathrm{~L}: 16 \mathrm{D})$ qu'en jour long (16L:8D). L'interruption de la phase obscure (7L : 9D : 1L : 7D) entraine une diminution brutale de la sécrétion de mélatonine qui ne réaugmente ensuite pendant la $2^{\mathrm{e}}$ période $\mathrm{d}^{\prime}$ obscurité que chez 6 brebis sur 8 .

$2^{\circ}$ ) Quatre groupes de 7 à 8 brebis adultes ont été soumis au moins pendant 6 mois à l'un des traitements lumineux suivants : $4 \mathrm{~L}: 8 \mathrm{D}, 4 \mathrm{~L}: 20 \mathrm{D}, 4 \mathrm{~L}: 32 \mathrm{D}$ ou $4 \mathrm{~L}: 44 \mathrm{D}$. Des prélèvements sanguins ont été effectués 2 fois par semaine pour suivre l'activité ovulatoire et la prolactine plasmatique. Des prélèvements horaires ont également été effectués Dendant $48 \mathrm{~h}$, un peu moins de 4 mois après le début de l'expérience pour analyser les niveaux plasmatiques de prolactine et de mélatonine.

L'activité ovulatoire ne permet pas de juger de la lecture photopériodique faite par les brebis dans les différents groupes. En revanche, l'évolution de la prolactine suggère que la lecture de la durée du jour par les brebis des groupes $4 \mathrm{~L}: 8 \mathrm{D}$ et $4 \mathrm{~L}: 32 \mathrm{D}$ est une lecture de jours longs alors que c'est une lecture de jours courts qui est faite par les animaux du groupe $4 \mathrm{~L}: 20 \mathrm{D}$. Quatre mois après le début de l'expérience un rythme de sécrétion de $24 \mathrm{~h}$ de la mélatonine persiste quel que soit le traitement photopériodique : il y a coïncidence, toutes les $24 \mathrm{~h}$, entre les différents groupes, des niveaux bas de mélatonine, 
d'une part, et des niveaux élevés, d'autre part. Des niveaux bas de mélatonine sont observés lors de toutes les périodes d'éclairement. La sécrétion de mélatonine est interrompue par la lumière dans les groupes $4 \mathrm{~L}: 8 \mathrm{D}$ et $4 \mathrm{~L}: 32 \mathrm{D}$ qui sont considérés comme des jours longs par les brebis.

Les résultats des deux expériences sont compatibles avec l'hypothèse selon laquelle les moments de sécrétion de mélatonine au cours du nycthémère sont plus importants pour la lecture de la durée du jour que la durée de sécrétion elle-même.

\section{References}

ALMEIDA O. F. X., LINCOLN G. A., 1982. Photoperiodic regulation of reproductive activity in the ram : evidence for the involvement of circadian rhythms in melatonin and prolactin secretion. Biol. Reprod., 27, 1062-1075.

BITTMAN E. L., KARSCH F. J., 1984. Nightly duration of pineal melatonin secretion determines the reproductive response to inhibitory day length in the ewe. Biol. Reprod., 30, 585-593.

BOISSIN-AGASSE L., JACQUET J. M., LACROIX A., BOISSIN J., 1986. Circadian participation in the photoregulation of testis activity and prolactin secretion in the mink, a short-day breeder. J. biol. Rhyt., 1, 231-241.

BRINKLOW B. R., FORBES J. M., RODWAY R. G., 1984. Melatonin in the plasma of growing sheep subjected to short and long photoperiods. Experientia, 40, 758-760.

CARTER D. S., GOLDMAN B. D., 1983. Antigonadal effects of timed melatonin infusion in pinealectomized male djungarian hamsters (Phodopus sungorus sungorus): duration is the critical parameter. Endocrinology, 113, 1261-1267.

D'OCCHIO M. J., SCHANBACHER B. D., KINDER J. E., 1984. Profiles of luteinizing hormone, follicle-stimulating hormone, testosterone and prolactin in rams of diverse breeds : effects of contrasting short $(8 \mathrm{~L}: 16 \mathrm{D})$ and long (16L : 8D) photoperiods. Biol. Reprod., 30, 1039-1054.

DUCKER M. J., BOWMAN J. C., TEMPLE A., 1973. The effect of constant photoperiod on the expression of oestrus in the ewe. J. Reprod. Fert., Suppl. 19, 143-150.

EARL C. R., D'OCCHIO M. J., KENNAWAY D. J., SEAMARK R. F., 1985 . Serum melatonin profiles and endocrine responses of ewes exposed to a pulse of light late in the dark phase. Endocrinology, 117, 226-230.

EARNEST D. J., TUREK F. W., 1983. Effect of one-second light pulses on testicular function and locomotor activity in the golden hamster. Biol. Reprod., 28, 557-565.

ELLIOTT J. A., STETSON M. H., MENAKER M., 1972. Regulation of testis function in golden hamsters : a circadian clock measures photoperiodic time. Science, 178, 771-773.

ELLIS D. H., FOLLETT B. K., 1983. Gonadotropin secretion and testicular function in golden hamsters exposed to skeleton photoperiods with ultrashort light pulses. Biol. Reprod., 29. 805-810.

FRASER S., COWEN P., FRANKLIN M., FRANEY C., ARENDT J., 1983. Direct radioimmunoassay for melatonin in plasma. Clin. Chem., 29, 396-397.

GOLDMAN B. D., 1983. The physiology of melatonin in mammals. In R. J. REITER, Pineal research reviews, 1, 147-177. Alan Liss, NY.

GOLDMAN B. D., DARROW J. M., 1983. The pineal gland and mammalian photoperiodism. Neuroendocrinology, 37, 386-396.

GROCOCK C. A., CLARKE J. R., 1974. Photoperiodic control of testis activity in the vole, Microtus agrestis. J. Reprod. Fert., 39, 337-347.

ILLNEROVA H., VANECEK J., 1982a. Two-oscillator structure of the pacemaker controlling the circadian rhythm of $\mathrm{N}$-acetyl-transferase in the rat pineal gland. J. comp. Physiol., 145, 539548.

ILLNEROVA $\mathrm{H}$., VANECEK J., 1982b. Complex control of the circadian rhythm in $\mathrm{N}$-acetyl transferase activity in the rat pineal gland, 285-296. In ASCHOFF J., DAAN S., GROSS G., Circadian systems : structure and function, Springer, Heidelberg.

KANN G., 1971. Dosage radioimmunologique de la prolactine plasmatique chez les ovins. $C$. $R$. Acad. Sci., Paris, 272, 2934-2938. 
KARSCH F. J., BITTMAN E. L., FOSTER O. L., GOODMAN R. L., LEGAN S. J., ROBINSON J. E., 1984. Neuroendocrine basis of seasonal reproduction. Recent Prog. Horm. Res., 40, 185-232.

LINCOLN G. A., ALMEIDA O. F. X., KLANDORF H., CUNNINGHAM R. A., 1982. Hourly fluctuations in the blood levels of melatonin, prolactin, luteinizing hormone, follicle-stimulating hormone, testosterone, triiodothyronine, thyroxine and cortisol in rams, under artificial photoperiods and the effect of cranial sympathectomy. J. Endocr., 92, 237-250.

LINCOLN G. A., EBLING F. V. P., ALMEIDA O. F. X., 1985. Generation of melatonin rhythms. In Photoperiodism, melatonin and the pineal, Ciba Found. Symp., 117, 120-141. Pitman, London.

MAEDA K., MORI Y., SAWASAKI T., KANO Y., 1984. Diurnal changes in peripheral melatonin concentration in goats and effects of light or dark interruption. Jap. J. vet. Sci, 46, 837-842.

NAMBOODIRI A., SUGDEN D., KLEIN D. C., GRADY R., MEFFORD I. N., 1985. Rapid noctural increase in ovine pineal $\mathrm{N}$-acetyl-transferase activity and melatonin synthesis : effects of cycloheximide. J. Neurochem., 451, 832-835.

ORTAVANT R., 1977. Photoperiodic regulation of reproduction in the sheep. In Management of reproduction in sheep and goats symposium, Univ. Wisconsin, 58-71.

PELLETIER J., 1973. Evidence for photoperiodic control of prolactin release in rams. J. Reprod. Fert., 35, 143-147.

PELletieR J., BLANC M., DAVEAU A., GARNIER D. H., de REVIERS M. M., TERQUI M., 1981. Mechanism of light action in the ram : a photosensitive phase for $L H, F S H$, testosterone and testis weight? 117-134. In ORTAVANT R., PELLETIER J., RAVAULT J. P., Photoperiodism and reproduction in vertebrates, INRA, Paris.

PELLETIER J., THIMONIER J., 1987. The measurement of daylength in the lle-de-France ram. J. Reprod. Fert., 81, 181-186.

POULTON A. L., ROBINSON T. J., 1987. The response of rams and ewes of three breeds to artificial photoperiod. J. Reprod. Fert., 79, 609-626.

RAVAULT J. P., 1976. Prolactin in the ram: seasonal variations in the concentration of blood plasma from birth until three years old. Acta Endocr., Copenh., 83, 720-725.

RAVAULT J. P., ORTAVANT R., 1977. Light control of prolactin secretion in sheep. Evidence for a photoinducible phase during a diurnal rhythm. Ann. Biol. anim. Biochim. Biophys., 17, 459-473.

RAVAULT J. P., DAVEAU A., ORTAVANT R., 1981. Evidence for a photosensitive phase for prolactin secretion in relation to the dusk in rams, 135-146. In ORTAVANT R., PELLETIER J., RAVAULT J. P., Photoperiodism and reproduction in vertebrates, INRA, Paris.

REITER R. J., HEINZELLER T., NURNBERGER F., 1986. A single 1 or 5 second light pulse at night inhibits hamster pineal melatonin. Endocrinology, 118, 1906-1909.

ROLLAG M. D., O'CALLAGHAN P. L., NISWENDER G. D., 1978. Serum melatonin concentration during different stages of the annual reproductive cycle in ewes. Biol. Reprod., 18, 279-285.

SCHANBACHER B. D., CROUSE J. D., 1981. Photoperiodic regulation of growth : a photosensitive phase during light-dark cycle. Am. J. Physiol., 241, E1-E5.

TERQUI M., THIMONIER J., 1974. Nouvelle méthode radio-immunologique rapide pour I'estimation du niveau de progestérone plasmatique. Application pour le diagnostic précoce de gestation chez la brebis et la chèvre. C. R. Acad. Sci., Paris, 279, 1109-1112.

THIMONIER J., 1978. L'activité ovarienne chez les bovins. Moyens d'étude et facteurs de variations. Ann. Méd. Vét., 122, 81-92.

THIMONIER J., 1981. Control of seasonal reproduction in sheep and goats by light hormones. J. Reprod. Fert., Suppl. 30, 33-45.

THIMONIER J., RAVAULT J. P., ORTAVANT R., 1978. Plasma prolactin variations and cyclic ovarian activity in ewes submitted to different light regimens. Ann. Biol. anim. Bioch. Biophys., 18, 1229-1235. 